\title{
Investigation of Affective and Socioeconomic Variables Predicting the Achievement Level of Low- and High-Achieving Students
}

\author{
Ercan Çoban (Corresponding author) \\ Department of Measurement and Evaluation, Ankara University, Turkey \\ E-mail: coban.ercan@gmail.com \\ Ömer Kamış \\ Department of Measurement and Evaluation, Ankara University, Turkey \\ E-mail: okamis87@gmail.com
}

Received: May 15, 2019 Accepted: June 25, 2019 Published: June 30, 2019

doi:10.5296/jei.v5i1.14792 URL: https://doi.org/10.5296/jei.v5i1.14792

\begin{abstract}
This study aimed to determine the affective and socioeconomic variables significantly predicting achievement level of low- and high-achieving students. The data of 1323 low-achieving and 2022 high-achieving Turkish students participated in the PISA 2015 were used in the study. The data were analyzed by using binary logistic regression. The findings showed that test anxiety; achievement motivation; enjoyment of cooperation; environmental awareness; environmental optimism; science self-efficacy; epistemological beliefs; economic, cultural and social status index (ESCS), and the information and communication technology (ICT) resources index were significant predictors of the achievement level of low- and high-achieving students. While test anxiety and environmental optimism scores of lowachieving students were higher, achievement motivation, enjoyment of cooperation, environmental awareness, science self-efficacy, epistemological beliefs, ESCS, and ICT resources scores were higher among high-achieving students.
\end{abstract}

Keywords: Science, Academic achievement, Affective variables, Socioeconomic variables, Low-achieving students, High-achieving students, PISA

\section{Introduction}

In today's world, the need for people having higher order cognitive skills has increased. 
Therefore, many countries aim to equip their citizens with skills like problem solving and creativity. In order to achieve this goal, countries need to determine effective educational policies. There are some international institutions that organize assessment programs to help countries develop educational policies. One of these programs is Programme for International Student Assessment (PISA).

PISA is an international assessment program arranged every three years since 2000. This program aims to evaluate academic achievement of 15-year-old students. In each cycle, one of three subject areas (reading, mathematics, and science) is determined as main area and assessed in detail. The main area in the PISA 2015 was science. Students from 72 countries and economies joined the PISA 2015. In PISA, data about student, school, teacher, and family characteristics related to student achievement are gathered, so that participating countries can use PISA results in development of educational policies. Contextual questionnaires, such as student, school, and parent questionnaires, are used to gather information about variables related to student achievement (OECD, 2016).

Turkey was one of the OECD member countries participating in the PISA 2015. Turkey's average science score in the PISA 2015 was lower than both general average and the OECD average. Turkey has ranked 54th among 72 participating countries in science (OECD, 2016). These results indicate that science achievement of Turkish students is low. Therefore, it is necessary to identify the variables associated with failure of Turkish students in science. Prior studies have found that various variables, such as students' affective (e.g., Anıl, 2009; Ceylan $\&$ Berberoglu, 2007) and socioeconomic (e.g., Anıl, 2009; Demir, 2016) characteristics are related to science achievement.

\subsection{Affective Variables and Achievement}

Data about students' affective characteristics are gathered in PISA cycles since these characteristics are related to academic achievement. As science was the main domain in the PISA 2015, affective variables included in this cycle were classified as general and science-related affective variables. General affective variables were test anxiety, sense of belonging to school, achievement motivation, value given to cooperation, and enjoyment of cooperation. Science-related affective variables were environmental awareness, environmental optimism, instrumental motivation, enjoyment of science, interest in broad science topics, science self-efficacy, and epistemological beliefs (OECD, 2016).

Test anxiety, which is one of the general affective variables, is a variable negatively affecting students' academic achievement (Cassady \& Johnson, 2002; Rana \& Mahmood, 2010). More specifically, it stems from worry about possible negative results of failing an exam (Zeidner, 1998). The impact of test anxiety on achievement is more evident, especially when test results are used in making important decisions about test takers (von der Embse \& Hasson, 2012). In previous cycles before the PISA 2015, it has been found that test anxiety significantly predicts academic achievement (OECD, 2016).

Sense of belonging is a feeling that motivates people to communicate with other people. People with a low sense of belonging are isolated from the community and are more likely to 
have problems of adjustment (Baumeister \& Leary, 1995). Sense of belonging to school refers to students' feelings of being supported, respected, and personally accepted in their school life (Goodenow \& Grady, 1993). Prior studies (e.g., Faircloth \& Hamm, 2005; Gonzalez \& Padilla, 1997) have found that student achievement has a positive association with sense of belonging. Sanchez, Colon, and Esparza (2005) found that absenteeism is common among students with a low sense of belonging to school. Absenteeism may be one of the reasons why academic achievement among students with low sense of school belonging is low.

Achievement motivation is the impulse that drives people to achieve their goals. Through this impulse, people set reachable goals and strive to achieve these goals (Atkinson \& Feather, 1966). Achievement motivation is an important factor that mobilizes students to reach their academic goals in the learning environment. Achievement motivation significantly predicts academic achievement, and students with high achievement motivation are more successful (Broussard \& Garrison, 2004).

Value given to cooperation and enjoyment of cooperation are among the affective variables assessed in the PISA 2015, because cooperative learning is related to academic achievement (OECD, 2016). Cooperative learning is a learning strategy in which students work together to accomplish learning activities and receive rewards based on group performance (Slavin, 2014). In this technique, students work on a common task by helping each other. Students both learn themselves and contribute to the learning of group mates (Johnson and Johnson, 1999). Hence, cooperative learning increases student achievement (Johnson \& Johnson, 2002; Slavin, 2014).

In addition to the general affective variables briefly discussed above, data about science-related affective variables were also gathered. Two of these variables are related to the environment: environmental awareness and environmental optimism. Environmental awareness is the student's level of knowledge about environmental problems, while environmental optimism is the student's level of optimism about environmental problems. These two environment-related variables affect students' sensitivity to environmental problems. Therefore, in the PISA 2015, some measurement instruments were used to determine the environmental awareness and environmental optimism level of students. By the environmental awareness scale, students' level of knowledge about greenhouse effect, genetically modified organisms (GMOs), air pollution, water scarcity, and nuclear waste were measured. By the environmental optimism scale, the views of students about how these environmental problems will change in the next 20 years were determined (OECD, 2016). Environmental problems are one of the application areas of theoretical knowledge learned in science courses. Hence, it is aimed to create environmental awareness of the students by including environment-related topics in the current science course curriculum developed by the Turkish authorities (MNE, 2018). Prior studies have found that both environmental awareness (e.g., Areepattamannil \& Kaur, 2013; de Regla, 2015; Thomson \& de Bortoli, 2008) and environmental optimism (e.g., Areepattamannil \& Kaur, 2013; Thomson \& de Bortoli, 2008) are associated with academic achievement. 
Three of the science-related affective variables covered in the PISA 2015 focuses on motivation. These variables are instrumental motivation, enjoyment of science, and interest in broad science topics. Instrumental motivation is the desire to learn because of a practical benefit or advantage that will be obtained as a result of learning (Clement, Gardner, \& Smythe, 1977). Instrumental motivation is a feature that encourages students to learn. It has been found in prior studies (e.g., Hong \& Ganapathy, 2017; Yu 2012) that instrumental motivation significantly predicts achievement. Consequently, a measurement instrument was used in the PISA 2015 to determine students' instrumental motivation for science learning. By this measurement instrument, students expressed their views on whether science learning will be beneficial for them in their future lives (OECD, 2016). Instrumental motivation refers to an external motivation. Alternatively, performing an activity because it is enjoyable or interesting is associated with intrinsic motivation (Ryan \& Deci, 2000). Therefore, it may be stated that students who like science or who are interested in science subjects have intrinsic motivation to learn science. Previous studies have showed that both enjoyment of science (e.g., Areepattamannil, Freeman, \& Klinger, 2011; Lam \& Lau, 2014) and interest in science (e.g., Areepattamannil, 2012; Chiu, 2010) are related to science achievement.

Another science-related affective variable is self-efficacy. It is the faith in one's own capacity to successfully fulfill a particular task (Bandura, 1997). Self-efficacy increases students' motivation and facilitates learning (Zimmerman, 2000). Therefore, self-efficacy and academic achievement are positively associated (Areepattamannil, Freeman, \& Klinger, 2011; Areepattamannil \& Kaur, 2013; Lam \& Lau, 2014).

The last science-related affective variable included in the PISA 2015 is epistemological belief. Epistemological beliefs refer to people's views about knowledge and knowing. These beliefs involve four dimensions, namely, certainty of knowledge, simplicity of knowledge, source of knowledge, and justification of knowledge (Hofer \& Pintrich, 1997). Prior researches have revealed that epistemological beliefs are associated with motivation (Molan \& Bostjancic, 2014), learning strategies (Metallidou, 2012; Tsai, 1998), and academic success (Conley, Pintrich, Vekiri, \& Harrison, 2004). Because of its role in the learning process, students' epistemological beliefs about science were assessed in the PISA 2015.

\subsection{Socioeconomic Status and Achievement}

One of the variables related to student achievement is students' socioeconomic status (SES). The association between SES and achievement has been investigated in many studies, and a positive relationship has generally been found between these two variables (e.g., McConney \& Perry, 2010; Millones, Ghesquiere, \& Leeuwen, 2014). Meta-analysis studies were carried out in different years by combining the results of many studies. White (1982) found that the correlation coefficient between socioeconomic status and student achievement ranges from $r$ $=.22$ to $\mathrm{r}=.73$, according to the way SES was defined. Sirin (2005) analyzed the studies published between the years 1990 and 2000 and found a moderate association between financial situation and achievement.

In the PISA, data are collected about various variables, such as parents' educational level and occupation, and cultural and technological properties in the home, to determine the 
socioeconomic status of students. Various indexes are derived from these data. In the PISA 2015, six indexes (i.e., cultural possessions at home, home educational possessions, home possessions, family wealth, economical, cultural and social status [ESCS], and information and communication technologies [ICT] resources) were calculated as SES indicators (OECD, 2016). These indexes are considered as SES indicators in this study.

When the literature is examined, it is evident that there are many studies attempting to determine students' affective and socioeconomic variables related to science achievement. However, these studies did not focus on students who are at lower and upper ends of the achievement distribution. Some of these studies have found that some variables have a weak or medium relationship with achievement. Focusing on low- and high-achieving students might help to identify variables that better explain the difference in achievement among students. Conducting a study with extreme achievement groups may enable us to better understand factors related to the achievement gap among students. Research conducted with such an approach might guide families, school administrators, and politicians about strategies to improve performance of low-achieving students. Moreover, the number of studies investigating both affective and socioeconomic variables is limited. By considering both affective and socioeconomic variables that may explain the difference in achievement among students, the amount of variance explained may be increased. The possible predictors of achievement will not be excluded. In large-scale assessment programs, such as PISA, a stratified random sampling method is used for sample selection. Therefore, sampling weights should be used in statistical analyses in order to correctly generalize the statistics obtained from sample to universe. Using sampling weights increases the external validity of research. For all these reasons, the current research aimed to identify the affective and socioeconomic variables predicting the achievement level of low- and high-achieving students who participated in the PISA 2015. The analyses were carried out by taking into consideration the sample weights and the following research questions were posed:

(1) What are the affective and socioeconomic variables that significantly predict the achievement level of students?

(2) Which predictors are more important in the prediction of achievement level of students?

(3) What is the correct classification percentage of the model consisting of the affective and socioeconomic variables?

\section{Method}

\subsection{Research Design}

The current research is a correlational study trying to identify students' affective and socioeconomic characteristics that predict their achievement level. Correlational studies aim to explain relationships between variables or to predict possible outcomes based on some models (Fraenkel \& Wallen, 2009). In addition, this research is a secondary analysis study based on the PISA 2015 data. Secondary analysis studies are carried out by re-analyzing the data collected by other researchers for different purposes (Neuman, 2014). 
2.2 Sample

Data of Turkish students who participated in the PISA 2015 were used in this study. There was a total of 5895 students in the original PISA 2015 Turkish sample. Since only 15-year-old students joined PISA, there were students from different grades in the Turkish sample. Majority of the students were ninth (20.70\%) and tenth graders (72.90\%). Low- and high- achieving students in this sample were determined based on PISA proficiency levels. Proficiency level 2 is a baseline level for scientific literacy. Students below proficiency level 2 are considered low-achievers in the PISA (OECD, 2016). Hence, the lower bound of proficiency level 2 (409.54) was used as cut score to classify students into one of two achievement groups (low or high). This procedure was repeated for all plausible values. Students who were in the low-achieving group regardless of the plausible value were included in the low-achieving group. Similarly, students who were in the high-achieving group regardless of the plausible value were included in the high-achieving group. As a result of this procedure, there were 1450 and 2082 students in the low-achieving and high-achieving groups, respectively. During the data-screening process, students with an extreme value in the predictor variables were excluded from the analysis. After eliminating the outliers, the low-achieving group consisted of 1323 students (671 girls and 652 boys), whereas the high-achieving group consisted of 2022 students (1053 girls and 969 boys). Consequently, statistical analyses were carried out with 3345 students.

\subsection{Data and Instruments}

Data of Turkish students joined the PISA 2015 were utilized in this study. The data were obtained from the OECD website. The data were gathered by student questionnaire and achievement test. This section provides information about the student questionnaire and achievement test used in the PISA 2015.

\subsubsection{Student Questionnaire}

The student questionnaire used in the PISA 2015 was developed by experts based on test construction procedures. The questionnaire collected information about both the demographic (e.g., gender, educational status and profession of parents, number of books at home, etc.) and affective (e.g., attitude, anxiety, motivation, etc.) characteristics of students. Based on data collected about students' demographic characteristics, some indexes, which are indicators of socioeconomic status of students, were derived in PISA. The indexes calculated in the PISA 2015 were cultural possessions at home, home educational possessions, home possessions, family wealth, economic, cultural and social status (ESCS), and information and communication technologies (ICT) resources (OECD, 2016). These indexes were considered socioeconomic predictor variables in the current study. While socioeconomic status is determined according to these indexes, affective characteristics are estimated by scores obtained from related scales.

Data about both general and science-related affective variables were collected by the PISA 2015 student questionnaire. Test anxiety, sense of belonging to school, achievement motivation, value given to cooperation, and enjoyment of cooperation were the general 
affective variables included in the questionnaire. Science-related affective variables were environmental awareness, environmental optimism, instrumental motivation, enjoyment of science, interest in broad science topics, science self-efficacy, and epistemological beliefs. All of the scales used to measure these variables were Likert-type scales (OECD, 2016). Table 1 provides information on the number of items and categories in the scales and Cronbach $\alpha$ values. Cronbach $\alpha$ values provided in Table 1 are the values calculated for Turkey.

Table 1. General information about the scales of affective variables

\begin{tabular}{|l|l|l|l|}
\hline Variable & Number of Items & Number of Category & Cronbach $\alpha$ \\
\hline Test Anxiety & 5 & 4 & 0.82 \\
\hline Sense of Belonging to School & 6 & 4 & 0.85 \\
\hline Achievement Motivation & 5 & 4 & 0.84 \\
\hline Value Given to Cooperation & 4 & 4 & 0.56 \\
\hline Enjoyment of Cooperation & 4 & 4 & 0.70 \\
\hline Environmental Awareness & 9 & 4 & 0.90 \\
\hline Environmental Optimism & 8 & 3 & 0.93 \\
\hline Instrumental Motivation & 4 & 4 & 0.90 \\
\hline Enjoyment of Science & 5 & 4 & 0.94 \\
\hline Interest in Broad Science Topics & 5 & 5 & 0.85 \\
\hline Science Self-efficacy & 8 & 4 & 0.89 \\
\hline Epistemological Beliefs & 6 & 4 & 0.92 \\
\hline
\end{tabular}

As seen in Table 1, the number of items in the scales range from four to nine. Category numbers are generally four. Cronbach $\alpha$ values indicating the reliability of the scales range from 0.56 to 0.94 . The scales generally have a high level of reliability.

\subsubsection{Achievement Test}

Student achievement is assessed by achievement tests in the PISA. The science achievement test applied in the PISA 2015 consisted of items about life sciences (36\%), physical sciences $(36 \%)$, and earth and space sciences (28\%). There were both multiple-choice and open-ended items in the test. In the PISA 2015, science achievement tests were administered via computer. A total of 66 forms were prepared for computer-based applications. Students were given one hour to respond to test items. Ten plausible values were computed for every student as an indicator of achievement (OECD, 2016). Plausible values are the values randomly selected from students' posterior achievement score distribution. The mean of students' posterior score distribution is equal to the expected a posteriori (EAP) estimate. Hence, EAP can be 
considered as average of an infinite number of plausible values (OECD, 2009).

\subsection{Data Analysis}

Binary logistic regression analysis was performed to identify the variables predicting achievement level of low- and high-achieving students. Achievement level consisting of two categories, low and high, was the dependent variable. The independent variables were the affective and socioeconomic variables discussed in the previous sections. Logistic regression analysis was performed with IDB Analyzer 4.0.21V developed by the International Association for the Evaluation of Educational Achievement (IEA). As this program takes into account sample weights, it increases the generalizability of the results obtained in the analyses to other students.

Assumptions of the logistic regression were tested before starting the analysis. Firstly, missing value analysis was performed and outliers were excluded. Then, it was verified whether there was a multicollinearity problem between the predictor variables. For missing value analysis, the Little MCAR test was carried out. Missing data did not satisfy the criteria for missing completely at random $(\operatorname{MCAR})\left(\chi^{2}(1687)=2134.97, p<0.05\right)$. When missing data patterns and separate variance t-tests results were examined, it was seen that data were missing at random (MAR). Because expectation maximization (EM) produces unbiased estimates with MAR data (Enders, 2010), missing data were imputed by the expectation maximization estimation method. Logistic regression analysis was conducted with and without outliers to see whether outliers influenced the results. Standard z scores for each variable were calculated to determine univariate outliers. Students whose z scores were not in the range of -3.29 to +3.29 were excluded. As a result of this procedure, data of 90 students (66 low-achievers and 24 high-achievers) were excluded from the analysis. Mahalanobis distances were calculated for multivariate outlier analysis. Data of 97 students (61 low-achievers and 36 high-achievers) were excluded from the analysis after multivariate outlier analysis. After univariate and multivariate outliers were excluded, data of the remaining 3345 students (1323 low-achiever and 2022 high-achiever) were used in the analyses. Since logistic regression is sensitive to high correlations among predictors (Tabachnick \& Fidell, 2007), it was verified whether there was a multicollinearity problem. Home possessions and family wealth indexes were removed from the analysis, since they showed high correlations with other socioeconomic variables. During the logistic regression analysis, low-performing students were coded as " 0 " and high-performing students were coded as "1". Low-performing students were identified as a reference category. The Statistics Packages for Social Sciences (SPSS) version 20.0 was used to test assumptions of logistic regression analysis. In logistic regression analysis, Cox \& Snell $\mathrm{R}^{2}$ and Nagelkerke $\mathrm{R}^{2}$ are used as effect size. Since Cox $\&$ Snell $R^{2}$ can never reach a maximum value of 1 (Tabachnick $\&$ Fidell, 2007), Nagelkerke $\mathrm{R}^{2}$ was used as the effect size in this study.

\section{Results}

Binary logistic regression analysis was used to identify general affective, science-related affective and socioeconomic variables significantly predicting students' achievement level. Analysis was repeated with and without outliers. Since outliers did not change the results, 
only the results of the analysis without the outliers were reported. Results of the analysis are provided in Table 2, and the correct classification rate of the model is provided in Table 3.

Table 2. Results of logistic regression model

\begin{tabular}{|c|c|c|c|c|c|c|c|c|}
\hline \multirow[t]{2}{*}{ Predictor } & \multirow[t]{2}{*}{ B } & \multirow[t]{2}{*}{ SE } & \multirow[t]{2}{*}{ Wald } & \multirow[t]{2}{*}{ df } & \multirow[t]{2}{*}{$\mathbf{p}$} & \multirow[t]{2}{*}{$\exp (B)$} & \multicolumn{2}{|c|}{$\begin{array}{l}95 \% \text { Confidence } \\
\text { Interval for } \exp (B)\end{array}$} \\
\hline & & & & & & & Lower & Upper \\
\hline Constant & 1.34 & 0.16 & 69.93 & 1 & $0.00 *$ & 3.82 & & \\
\hline Test Anxiety & -0.43 & 0.07 & 36.87 & 1 & $0.00 *$ & 0.65 & 0.56 & 0.74 \\
\hline Sense of Belonging to School & 0.00 & 0.05 & 0.00 & 1 & 0.95 & 1.00 & 0.89 & 1.10 \\
\hline Achievement Motivation & 0.13 & 0.06 & 5.33 & 1 & $0.02 *$ & 1.14 & 1.01 & 1.27 \\
\hline Enjoyment of Cooperation & 0.23 & 0.07 & 10.78 & 1 & $0.00 *$ & 1.26 & 1.09 & 1.42 \\
\hline Value Given to Cooperation & -0.02 & 0.06 & 0.13 & 1 & 0.72 & 0.98 & 0.86 & 1.10 \\
\hline Environmental Awareness & 0.40 & 0.04 & 81.07 & 1 & $0.00 *$ & 1.49 & 1.36 & 1.62 \\
\hline Environmental Optimism & -0.67 & 0.04 & 285.04 & 1 & $0.00 *$ & 0.51 & 0.47 & 0.55 \\
\hline Enjoyment of Science & 0.09 & 0.06 & 2.03 & 1 & 0.15 & 1.09 & 0.96 & 1.23 \\
\hline Interest in Broad Science Topics & -0.09 & 0.06 & 2.38 & 1 & 0.12 & 0.91 & 0.80 & 1.02 \\
\hline Instrumental Motivation & -0.03 & 0.06 & 0.22 & 1 & 0.64 & 0.97 & 0.85 & 1.09 \\
\hline Science Self-efficacy & 0.12 & 0.05 & 6.15 & 1 & $0.01 *$ & 1.13 & 1.02 & 1.23 \\
\hline Epistemological Beliefs & 0.41 & 0.05 & 58.38 & 1 & $0.00 *$ & 1.51 & 1.35 & 1.67 \\
\hline Home Educational Possessions & -0.08 & 0.06 & 1.71 & 1 & 0.19 & 0.92 & 0.81 & 1.03 \\
\hline Cultural Possessions at Home & 0.05 & 0.08 & 0.44 & 1 & 0.51 & 1.05 & 0.90 & 1.21 \\
\hline ESCS & 0.27 & 0.08 & 11.57 & 1 & $0.00 *$ & 1.32 & 1.11 & 1.53 \\
\hline ICT Resources & 0.72 & 0.10 & 56.78 & 1 & $0.00 *$ & 2.06 & 1.67 & 2.45 \\
\hline \multicolumn{9}{|l|}{ Nagelkerke $\mathrm{R}^{2}=0.52$} \\
\hline
\end{tabular}

Note. ${ }^{*} \mathrm{p}<0.05$.

As summarized in Table2, the model explained $52 \%$ of the variance in achievement level (Nagelkerke $\mathrm{R}^{2}=0.52$ ). According to the Omnibus test, the model was significantly better at predicting students' achievement level than the baseline model $\left(\chi^{2}(16)=258054.11, \mathrm{p}<0.05\right)$. According to Wald statistics, test anxiety, achievement motivation, enjoyment of cooperation, environmental awareness, environmental optimism, science self-efficacy, epistemological 
beliefs, ESCS, and ICT resources were significant predictors of students' achievement level. While test anxiety and environmental optimism decreased the odds of being a high-achieving student, other significant predictors increased the odds of being a high-achieving student. ICT resources (odds ratio $=2.06$ ) caused the highest increase in the odds of being a high-achieving student, whereas environmental optimism (odds ratio $=0.51$ ) caused the highest decrease in the odds of being a high-achieving student. The model correctly predicted achievement level of $68.40 \%$ of low-achieving students and $88.30 \%$ of high-achieving students. The model correctly classified $80.42 \%$ of all students (Table 3 ).

Table 3. Classification table for the model

\begin{tabular}{|l|l|l|l|l|}
\hline \multirow{2}{*}{} & \multirow{2}{*}{ Achievement Level } & \multicolumn{2}{|c|}{ Predicted } & \multirow{2}{*}{ Correct Classification Percentage } \\
\cline { 2 - 4 } & & Low & High & \\
\hline \multirow{2}{*}{ Observed } & Low & 905 & 418 & $68.40 \%$ \\
\cline { 2 - 5 } & High & 237 & 1785 & $88.30 \%$ \\
\hline \multirow{2}{*}{ Overall Correct Classification Percentage } & $80.42 \%$ \\
\hline
\end{tabular}

\section{Discussion and Conclusion}

The results of the study showed that general affective variables significantly predicting students' achievement level were test anxiety, achievement motivation, and enjoyment of cooperation. Students with high test anxiety were more likely to be in the low-achieving group. This result shows that high-achieving students have lower test anxiety. Therefore, it may be concluded that test anxiety is a variable decreasing academic achievement. Previous literature (Cassady \& Johnson, 2002; Rana \& Mahmood, 2010) support this finding. The negative impact of test anxiety on student achievement may be reduced. Educational guidance activities (e.g., personal counseling, seminars, etc.) organized by school counselors may help students cope with test anxiety.

According to the findings of the current study, students with high achievement motivation were more likely to be in the high-achieving group. This finding, which is consistent with the literature (Broussard \& Garrison, 2004; Steinmayr \& Spinath, 2009), reveals that achievement motivation is an important predictor of achievement level. Enjoyment of cooperation is the other general affective variable significantly predicting students' achievement level. Students with a high level of enjoyment of cooperation were more likely to be in the high-achieving group. This result can be explained by the role of cooperative learning in student achievement. Cooperative learning has been found to be a learning strategy that increases student achievement (Johnson \& Johnson, 2002; Slavin, 2014). Students contribute to each other's learning in the process of cooperative learning (Johnson \& Johnson, 1999). A high level of enjoyment of cooperation among high-achieving students may be related to the contribution of cooperation to their learning process. Students may 
consider this contribution a reinforcer for cooperation. Due to the positive role of cooperative learning, teachers should encourage students to engage in group work during classroom activities.

Science-related affective variables significantly predicting students' achievement level were environmental awareness, environmental optimism, science self-efficacy, and epistemological beliefs. Students with high environmental awareness were more likely to be in the high-achieving group, whereas students with high environmental optimism were more likely to be in the low-achieving group. It is seen that high-achieving students have high environmental awareness and low environmental optimism. These results, which are consistent with the previous literature (Areepattamannil \& Kaur, 2013; Thomson \& de Bortoli, 2008), indicate that high-achieving students have more knowledge than low-achieving ones about environmental problems, such as the greenhouse effect, genetically modified organisms (GMOs), air pollution, water scarcity, and nuclear waste. Low-achieving students are more optimistic about environmental problems. They think that environmental problems will improve in the next 20 years. Their optimism about environmental problems may be due to a lack of environmental awareness. Because of the importance of environmental awareness, environmental issues have been included in updated science education curriculum in Turkey (MNE, 2018). Teachers should effectively apply this curriculum to foster environmental awareness among students.

Students with high science self-efficacy were more likely to be in the high-achieving group. This finding may be related to the role of self-efficacy on motivation and learning. (Zimmerman, 2000). Previous studies (Areepattamannil, Freeman, \& Klinger, 2011; Areepattamannil \& Kaur, 2013; Lam \& Lau, 2014) have found a positive relationship between self-efficacy and achievement. This study confirms the findings of previous studies.

Results of the current study indicated that epistemological beliefs about science significantly predicted science achievement. Students with higher scores on the epistemological beliefs scale were more likely to be in the high-achieving group. Students who scored high on PISA 2015 epistemological beliefs scale believed that scientific knowledge changes over time. Moreover, they believed in the importance of doing experiments for production and justification of scientific knowledge (OECD, 2016). Hence, it can be concluded that successful students have a critical view of scientific knowledge. Studies that have found a positive relationship between achievement and critical thinking (e.g., Stupnisky, Renaud, Daniels, Haynes, \& Perry, 2008; Villavicencio, 2011) support this inference.

ESCS and ICT resources indexes were the socioeconomic variables that significantly predicted students' achievement level. Students with a high ESCS index were more likely to be in the high-achieving group. The ESCS index is calculated based on parental education, highest parental occupation, and home possessions (OECD, 2017). Therefore, it may be concluded that parents of high-achieving students have higher educational levels and occupational statuses than parents of low-achieving students. This inference is supported by studies that have found that parental education (e.g., An1l, 2009; Tanskanen, Erola, \& Kallio, 2016) and occupation (e.g., Alade, Nwadingwe, \& Victor, 2014; Usaini \& Abubakar, 2015) 
are positively associated with student achievement. Parents who have high educational levels and occupational statuses can easily provide educational resources needed by their children. This situation may be a possible explanation of higher academic achievement among students with a high ESCS index.

ICT resources index, which is calculated based on the technological resources students have, was the best predictor of students' achievement level among all affective and socioeconomic variables. Students with a high ICT resources index were more likely to be in the high-achieving group. This finding, which is similar to previous literature (e.g., Chandra \& Lloyd, 2008; Demir, 2016), reveals that there is a big difference between low- and high-performing students in terms of ICT resources existing in their homes. High academic achievement of students with a high ICT resources index may be due to the fact that ICT resources facilitate access to knowledge. Educational software and the Internet, in particular, may have a positive impact on the learning process of students. Relevant authorities should give support to students who have limited access to ICT resources for equal opportunity in education.

Some variables included in this study were not a significant predictor of students' achievement level. These variables were sense of belonging to school, value given to cooperation, instrumental motivation, enjoyment of science, interest in broad science topics, cultural possessions at home, and home educational possessions. There are some studies in the literature showing that these variables are related to academic achievement (e.g. Areepattamannil, 2012; Chiu, 2010; Faircloth \& Hamm, 2005; Hong \& Ganapathy, 2017; Lam \& Lau, 2014; Martins \& Veiga, 2010; Pokropek, Borgonovi, \& Jakubowski, 2015; Yu, 2012). The discrepancy between the current study and previous studies may be due to methodological differences. In this study, students were divided into two extreme groups based on their achievement. By such an approach, it was aimed to identify variables that best explain the difference in achievement among students. Low- and high-achieving students may not be sufficiently differentiated in terms of the above variables. Consequently, students with different achievement levels may be similar in terms of these variables. Another reason for the discrepancy between the current study and previous studies may be the size of the relationships obtained in the previous studies. Variables that have a weak or medium relationship with academic achievement may be unable to distinguish between low- and high-achieving students.

The current study contributes to the existing literature; however, there are some limitations of the study. First, only the affective and socioeconomic characteristics of students were taken into consideration in this study. Future studies can be conducted by considering teacher (i.e., experience, education level, classroom management, etc.) and school (i.e., class size, number of teachers, etc.) characteristics, which may be related to student achievement. Second, the use of data from only the Turkish students is another limitation of this research. Researchers can conduct similar studies by using data from different countries for cross-cultural comparison of the results. Nevertheless, despite its limitations, the current study provides important insight to the differences in achievement between low- and high-achieving students in Turkey. 


\section{References}

Alade, O. M., Nwadingwe, I. P., \& Victor, I. (2014). Socio-economic status and gender as predictors of students' academic achievement in economics. Journal of Education and Practice, 5(9), 96-110.

An1l, D. (2009). Factors effecting science achievement of science students in Programme for International Student Assessment (PISA) in Turkey. Education and Science, 34(152), 87-100.

Areepattamannil, S. (2012). Effects of inquiry-based science instruction on science achievement and interest in science: Evidence from Qatar. The Journal of Educational Research, 105, 134-146. https://doi.org/10.1080/00220671.2010.533717

Areepattamannil, S., \& Kaur, B. (2013). Factors predicting science achievement of immigrant and non-immigrant students: A multilevel analysis. International Journal of Science and Mathematics, 11, 1183-1207.

Areepattamannil, S., Freeman, J. G., \& Klinger, D. A. (2011). Influence of motivation, self-beliefs, and instructional practices on science achievement of adolescents in Canada. Social Psychology of Education, 14(2), 233-259.

Atkinson, J. W., \& Feather, N. T. (1966). A theory of achievement motivation. New York, NY: John Wiley and Sons.

Bandura, A. (1997). Self-efficacy: The exercise of control. New York, NY: W.H. Freeman and Company.

Baumeister, R. F., \& Leary, M. R. (1995). The need to belong: Desire for interpersonal attachments as a fundamental human motivation. Psychological Bulletin, 117(3), 497-529.

Broussard, S. C., \& Garrison, M. E. (2004). The relationship between classroom motivation and academic achievement in elementary school-aged children. Family Consumer Science Research Journal, 33(2), 106-120.

Cassady, J. C., \& Johnson, R. E. (2002). Cognitive test anxiety and academic performance. Contemporary Educational Psychology, 27(2), 270-295.

Ceylan, E., \& Berberoglu, G. (2007). Factors related with students' science achievement: A modeling study. Education and Science, 32(144), 36-48.

Chandra, V., \& Lloyd, M. (2008). The methodological nettle: ICT and student achievement. British Journal of Educational Technology, 39(6), 1087-1098.

Chiu, M.-S. (2010) Effects of science interest and environmental responsibility on science aspiration and achievement: Gender differences and cultural supports. Educational Research and Evaluation, 16(4), 345-370. https://doi.org/10.1080/13803611.2010.527756

Clément, R., Gardner, R. C., \& Smythe, P. C. (1977). Motivational variables in second language acquisition: A study of Francophones learning English. Canadian Journal of Behavioural Science, 9(2), 123-133. https://doi.org/10.1037/h0081614 
Conley, A. M. M., Pintrich, P. R., Vekiri, I., \& Harrison, D. (2004). Changes in epistemological beliefs in elementary science students. Contemporary Educational Psychology, 29(2), 186-204. https://doi.org/10.1016/j.cedpsych.2004.01.004

De Regla, E. N. (2015). The relationship of environmental awareness in selected topics in science and academic performance of education students in Bulacan State University-Bustos Campus, Philippines. International Journal of Scientific and Research Publications, 5(8), 349-353.

Demir, E. (2016). Characteristics of 15-year-old students predicting scientific literacy skills in Turkey. International Education Studies, 9(4), 99-107. https://doi.org/10.5539/ies.v9n4p99

Enders, C. K. (2010). Applied missing data analysis. New York, NY: The Guilford Press.

Faircloth, B. S., \& Hamm, J. V. (2005). Sense of belonging among high school students representing 4 ethnic groups. Journal of Youth and Adolescence, 34(4), 293-309. https://doi.org/10.1007/s10964-005-5752-7

Fraenkel, J. R., \& Wallen, N. E. (2009). How to design and evaluate research in education (7th ed.). New York, NY: McGraw-Hill.

Gonzalez, R., \& Padilla, A. M. (1997). The academic resilience of Mexican American high school students. Hispanic Journal of Behavioral Sciences, 19(3), 301-317.

Goodenow, C., \& Grady, K. E. (1993). The relationship of school belonging and friends' values to academic motivation among urban adolescent students. Journal of Experimental Education, 62(1), 60-71.

Hofer, B. K., \& Pintrich, P. R. (1997). The development of epistemological theories: Beliefs about knowledge and knowing and their relation to learning. Review of Educational Research, 67(1), 88-140.

Hong, Y. C., \& Ganapathy, M. (2017). To investigate ESL students' instrumental and integrative motivation towards English language learning in a Chinese school in Penang: Case study. English Language Teaching, 10(9), 17-35. https://doi.org/10.5539/elt.v10n9p17

Johnson, D. W., \& Johnson, R. T. (1999). Making cooperative learning work. Theory into Practice, 38(2), 67-73.

Johnson, D. W., \& Johnson, R. T. (2002). Learning together and alone: Overview and meta-analysis. Asia Pacific Journal of Education, 22(1), 95-105.

Lam, T. Y. P., \& Lau, K. C. (2014). Examining factors affecting science achievement of Hong Kong in PISA 2006 using hierarchical linear modeling. International Journal of Science Education, 36(15), 2463-2480. https://doi.org/10.1080/09500693.2013.879223

Martins, L., \& Veiga, P. (2010). Do inequalities in parents' education play an important role in PISA students' mathematics achievement test score disparities? Economics of Education Review, 29(6), 1016-1033. https://doi.org/10.1016/j.econedurev.2010.05.001 
McConney, A., \& Perry, L. B. (2010). Science and mathematics achievement in Australia: The role of school socioeconomic composition in educational equity and effectiveness. International Journal of Science and Mathematics Education, 8(3), 429-452. https://doi.org/ 10.1007/s10763-010-9197-4

Metallidou, P. (2012). Epistemological beliefs as predictors of self-regulated learning strategies in middle school students. School Psychology International, 34(3), 283-298. https://doi.org/10.1177/0143034312455857

Millones, D. L. M., Ghesquiere, P., \& Leeuwene, K. V. (2014). Relationship among parenting behavior, SES, academic achievement and psychosocial functioning in Peruvian children. Universitas Psychologica, 13(2), 639-650. https://doi.org/10.11144/Javeriana.UPSY13-2.rpba

Ministry of National Education (MNE). (2018). Science curriculum: Primary and secondary school 3, 4, 5, 6, 7 and 8th grades. Retrieved from http://mufredat.meb.gov.tr

Molan, I., \& Bostjancic, E. (2014). How do epistemological beliefs affect training motivation? Dynamic Relationships Management Journal, 3(1), 57-68.

Neuman, W. L. (2014). Social research methods: Quantitative and qualitative approaches (7th ed.). Essex: Pearson Education.

OECD. (2009). PISA data analysis manual. Paris: OECD Publishing.

OECD. (2016). PISA 2015 assessment and analytical framework science, reading, mathematics and financial literacy. Paris: OECD Publishing.

OECD. (2017). PISA 2015 technical report. Paris: OECD Publishing.

Pokropek, A., Borgonovi, F., \& Jakubowski, M. (2015). Socio-economic disparities in academic achievement: A comparative analysis of mechanisms and pathways. Learning and Individual Differences, 42, 10-18. https://doi.org/10.1016/j.lindif.2015.07.011

Rana, R. A., \& Mahmood, N. (2010). The relationship between test anxiety and academic achievement. Bulletin of Education and Research, 32(2), 63-74.

Ryan, R. M., \& Deci, E. L. (2000). Intrinsic and extrinsic motivations: Classic definitions and new directions. Contemporary Educational Psychology, 25(1), 54-67.

Sanchez, B., Colon, Y., \& Esparza, P. (2005). The role of sense of school belonging and gender in the academic adjustment of Latino adolescents. Journal of Youth and Adolescence, 34(6), 619-628. https://doi.org/10.1007/s10964-005-8950-4

Sirin, S. R. (2005). Socioeconomic status and academic achievement: a meta-analytic review of research. Review of Educational Research, 75(3), 417-453.

Slavin, R. E. (2014). Cooperative learning and academic achievement: Why does group-work work? Anales de Psicologia, 30(3), 785-791.

Steinmayr, R., \& Spinath, B. (2009). The importance of motivation as a predictor of school achievement. Learning and Individual Differences, 19(1), 80-90. 
Stupnisky, R. H., Renaud, R. D., Daniels, L. M., Haynes, T. L., \& Perry, R. P. (2008). The interrelation of first-year college students' critical thinking disposition, perceived academic control, and academic achievement. Research in Higher Education, 49, 513-530. https://doi.org/10.1007/s11162-008-9093-8

Tabachnick, B. G., \& Fidell, L. S. (2007). Using multivariate statistics (5th ed.). Boston, MA: Pearson Education.

Tanskanen, A. O., Erola, J., \& Kallio, J. (2016). Parental resources, sibship size, and educational performance in 20 countries: Evidence for the compensation model. Cross-Cultural Research, 50(5), 452-477. https://doi.org/10.1177/1069397116671139

Thomson, S., \& de Bortoli, L. (2008). Exploring scientific literacy: How Australia measures up. Camberwell: ACER Press.

Tsai, C. C. (1998). An analysis of scientific epistemological beliefs and learning orientations of Taiwanese eighth graders. Science Education, 82(4), 473-489.

Usaini, M. I., \& Abubakar, N. B. (2015). The impact of parents' occupation on academic performance of secondary school students in Kuala Terengganu. Multilingual Academic Journal of Education and Social Sciences, 3(1), 112-120. https://doi.org/10.6007/MAJESS/ v3-i1/1899

Villavicencio, F. T. (2011). Critical thinking, negative academic emotions, and achievement: A mediational analysis. The Asia-Pacific Education Researcher, 20(1), 118-126.

Von der Embse, N. \& Hasson, R. (2012). Test anxiety and high-stakes test performance between school settings: Implications for educators. Preventing School Failure: Alternative Education for Children and Youth, 56(3), 180-187.

White, K. R. (1982). The relation between socioeconomic status and academic achievement. Psychological Bulletin, 91(3), 461-481.

Yu, C. H. (2012). Examining the relationships among academic self-concept, instrumental motivation, and TIMSS 2007 science scores: A cross-cultural comparison of five East Asian countries/regions and the United States. Educational Research and Evaluation, 18(8), 713-731. https://doi.org/10.1080/13803611.2012.718511

Zeidner, M. (1998). Test anxiety: The state of the art. New York, NY: Plenum Publishers.

Zimmerman, B. J. (2000). Self-efficacy: An essential motive to learn. Contemporary Educational Psychology, 25(1), 82-91.

\section{Copyright Disclaimer}

Copyright for this article is retained by the author(s), with first publication rights granted to the journal.

This is an open-access article distributed under the terms and conditions of the Creative 
Commons Attribution license (http://creativecommons.org/licenses/by/3.0/). 